\title{
Are problem drinkers dangerous drivers? An investigation of arrest for drinking and driving, serum $\gamma$ glutamyltranspeptidase activities, blood alcohol concentrations, and road traffic accidents: the Tayside Safe Driving Project
}

\author{
JAMES A DUNBAR, SIMON A OGSTON, A RITCHIE, M S DEVGUN, JAMES HAGART,
} BRIAN T MARTIN

\begin{abstract}
Serum $\gamma$ glutamyltranspeptidase activity was measured in $\mathbf{4 4 0}$ drivers at the time of arrest for driving under the influence of alcohol. The results were compared with information gathered by the arresting police officer. One third of drivers over the age of 30 had abnormal $\gamma$ glutamyltranspeptidase activities at the time of arrest. Among drivers who required a driving licence for their work, and older drivers, a disproportionately high number had raised $\gamma$ glutamyltranspeptidase activities indicating problem drinking. In drivers over the age of 30 a strong association was found between $\gamma$ glutamyltranspeptidase activities and road
\end{abstract}

\footnotetext{
Departments of Forensic, Community and Occupational, and Biochemical Medicine, University of Dundee, and Tayside Police, Scotland

JAMES A DUNBAR, MRCGP, DMJ, police surgeon and honorary lecturer in forensic medicine

SIMON A OGSTON, MA, MSC, medical statistician

A RITCHIE, chief inspector

Department of Biochemistry, Law Hospital, Carluke, Lanarkshire

M S DEVGUN, PHD, MIBIOL, senior clinical biochemist
}

Social Psychology Research Unit, University of Kent, Canterbury, Kent JAMES HAGART, MSC, research fellow

Area Department of Pathology, Exeter, Devon

BRIAN T MARTIN, BSC, PHD, principal biochemist

Correspondence to: Dr J A Dunbar, Department of Forensic Medicine, Royal Infirmary, Dundee DD1 9ND. traffic accidents but not alcohol concentrations or previous convictions.

These findings argue against the Department of Transport's criteria for high risk offenders and indicate a clear need for new measures against problem drinkers among drinking and driving offenders.

\section{Introduction}

In 1976 the Blennerhassett Committee recommended that those at high risk among drinking and driving offenders should be identified.' Since May 1983 the Road Traffic Act has defined high risk offenders as drivers who are convicted of drinking and driving on two occasions within 10 years and have alcohol concentrations two and a half times the legal limit or refuse to provide a specimen. High risk drivers are investigated by the medical advisers of the Department of Transport for evidence of dependence on alcohol or other drinking problems. This implies that problem drinking, as distinct from driving under the influence of alcohol, is accepted as an important factor in traffic safety.

The relation between alcohol concentrations and road traffic accidents has been accepted for two decades and is the rationale underlying drinking and driving laws in many countries. ${ }^{2}$ Most previous studies of road traffic accidents have used stated alcohol consumption or alcohol concentrations, or both, to identify problem drivers, although the accuracy of these methods is in doubt and alcohol concentrations are dependent on the time elapsed between alcohol consumption and arrest. Recent research has also shown that the relation between alcohol concentrations and accidents is complicated by other factors, ${ }^{34}$ and particular attention 
has been paid to the effects of age and problem drinking. ${ }^{5-9}$ Evidence submitted to the Blennerhassett Committee by the British Medical Association and the Medical Commission on Accident Prevention favoured a single, lower, criterion blood alcohol concentration of 33 $\mathrm{mmol} / 1(150 \mathrm{mg} / 100 \mathrm{ml})$ indicating potential problem drinking. Little research into high risk offenders has been conducted, and it remains to be shown that high risk offenders as defined in the Road Traffic Act are synonymous with those offenders whom Blennerhassett sought to identify. ${ }^{9}$

Serum enzyme $\gamma$ glutamyltranspeptidase activity is generally accepted to be a reasonably sensitive indicator of chronic excessive alcohol consumption ${ }^{10-12}$ and has been used in four studies of drivers. ${ }^{13-16}$ As a single drinking binge does not increase $\gamma$ glutamyltranspeptidase activities in drivers with either normal or abnormal activities the activity of the enzyme measured at the time of arrest has been recommended as a simple way of helping to identify many people who chronically consume excessive amounts of alcohol. ${ }^{15} \mathrm{We}$ undertook the following examination of the relations between $\gamma$ glutamyltranspeptidase activities, alcohol concentrations, age, and accidents among drivers arrested for drinking and driving to help clarify the position regarding alcohol consumption and road traffic accidents and facilitate the assessment of offenders who are also problem drinkers.

\section{Subjects and methods}

Motorists arrested for drinking and driving in Tayside Region over one year and opting to give a blood sample were invited to participate in this study; $440(96 \%)$ (of whom $429(97 \cdot 5 \%)$ were men) agreed to do so.

At the time of arrest $5 \mathrm{ml}$ blood was taken and divided into three samples: one was given to the driver, the second was analysed for blood alcohol concentration by the public analyst, and the third was used to measure the serum activity of $\gamma$ glutamyltranspeptidase using a centrifugal fast analyser $\left(37^{\circ} \mathrm{C}\right)$. Other liver enzyme tests were not carried out because of sample instability. ${ }^{17}$ An examination to detect drugs or diseases known to raise serum $\gamma$ glutamyltranspeptidase activity was carried out, but none such was detected.

The arresting police officer filled out a questionnaire for all drivers. This identified the type of vehicle being driven, whether the driver was the owner, the reason for the arrest, whether the driver was involved in an accident, and whether he required a driving licence for his job. With the driver's consent a list of his previous drinking and driving convictions was obtained from the police computer. Only $23(5 \cdot 3 \%)$ of participants refused this consent. In subsequent tables blood alcohol concentration is categorised as greater or less than $33 \mathrm{mmol} / \mathrm{l}$, a limit that conforms with the British Medical Association's recommended criterion of high risk offenders and corresponded to the approximate median concentration of the sample. In addition, $50 \mathrm{IU} / \mathrm{l}$ was used as the limit to define high and low $\gamma$ glutamyltranspeptidase activities. Significance tests for categorical data were used-namely, Fisher's exact test for $2 \times 2$ contingency tables and $\chi^{2}$ tests for larger tables.

\section{Results}

Table I shows the distribution of variables recorded by the arresting officer across three age groups (under $30,30-44$, and 45 and over). This indicates that a third of the drivers had been arrested for impaired driving and a quarter had been involved in an accident. Significant differences were evident across age groups for all variables except the proportion of drivers who had been involved in accidents.

Table II shows the numbers and proportions of subjects who had raised $\gamma$ glutamyltranspeptidase activities, tabulated by age and variables in the police questionnaire. Overall, one fifth (91) of the drivers had raised $\gamma$ glutamyltranspeptidase activities, the prevalence being $10 \cdot 2 \%, 31 \cdot 5 \%$, and $29.3 \%$ in drivers aged under $30,30-44$, and 45 and over, respectively. Among young drivers the only significant difference in $\gamma$ glutamyltranspeptidase activities was associated with type of vehicle driven, drivers of heavy goods or commercial vehicles contributing disproportionately to the number of people with a raised $\gamma$ glutamyltranspeptidase activity. Among drivers in the 30-44 age group there were significant differences in $\gamma$ glutamyltranspeptidase activities associated with reasons for arrest, accident involvement, and whether driving licences were required for the driver's occupation. In the 45 and over age group reasons for arrest showed a significant relation. Raised $\gamma$ glutamyltranspeptidase activities were more common in drivers involved in accidents and arrested as the result of an accident and in those who required a driving licence for their jobs, including drivers of public service and heavy goods vehicles. There was no significant relation between previous drinking and driving convictions and raised $\gamma$ glutamyltranspeptidase activities.

Table III summarises the interrelation between blood alcohol concentration, $\gamma$ glutamyltranspeptidase activities involvement, and age for 377 drivers across two age groups (under 30 and over 30 ) on whom complete information was available. Of drivers aged below 30, only one of those involved in an accident $(2 \cdot 4 \%)$ had a high $\gamma$ glutamyltranspeptidase activity.

TABLE I-Distribution of police questionnaire variables by age. Figures indicate numbers (\%) subjects

\begin{tabular}{|c|c|c|c|c|c|}
\hline & \multicolumn{3}{|c|}{ Subjects aged: } & \multirow{2}{*}{ Total } & \multirow{2}{*}{ Significance $^{\star}$} \\
\hline & $\begin{array}{c}<30 \\
\text { years } \dagger\end{array}$ & $\begin{array}{l}30-44 \\
\text { yearsł }\end{array}$ & $\begin{array}{l}\geqslant 45 \\
\text { years } \$\end{array}$ & & \\
\hline $\begin{array}{l}\text { Blood alcohol concentration } \\
<33 \mathrm{mmo} / 1 \\
\geqslant 33 \mathrm{mmol} / 1 \\
\text { Unknown } \\
\text { Total }\end{array}$ & $\begin{array}{r}110(61 \cdot 5) \\
69(38 \cdot 5) \\
37 \\
179\end{array}$ & $\begin{array}{l}54(41 \cdot 5) \\
76(58 \cdot 5) \\
19 \\
130\end{array}$ & $\begin{array}{l}27(39 \cdot 7) \\
41(60 \cdot 3) \\
7 \\
68\end{array}$ & $\begin{array}{l}191(50 \cdot 7) \\
186(49 \cdot 3) \\
63 \\
377\end{array}$ & $\left\{\begin{array}{l}x_{2}^{2}=15 \cdot 9 \\
p<0.001\end{array}\right.$ \\
\hline $\begin{array}{l}\text { Car owner: } \\
\text { Yes } \\
\text { No }\end{array}$ & $\begin{array}{r}135(62 \cdot 5) \\
81(37 \cdot 5)\end{array}$ & $\begin{array}{r}109(73 \cdot 2) \\
40(26 \cdot 8)\end{array}$ & $\begin{array}{l}60(80 \cdot 0) \\
15(20 \cdot 0)\end{array}$ & $\begin{array}{l}304(69 \cdot 1) \\
136(30 \cdot 9)\end{array}$ & $\left\{\begin{array}{l}x_{2}^{2}=9 \cdot 7 \\
p<0 \cdot 01\end{array}\right.$ \\
\hline $\begin{array}{l}\text { Reason for arrest: } \\
\text { Moving traffic offence } \\
\text { Routine stop } \\
\text { Impaired driving } \\
\text { Information received } \\
\text { Accident } \\
\text { Other } \\
\text { Total }\end{array}$ & $\begin{array}{r}63(30 \cdot 1) \\
31(14 \cdot 8) \\
63(30 \cdot 1) \\
8(3 \cdot 8) \\
44(21 \cdot 1) \\
7 \\
209\end{array}$ & $\begin{array}{l}28(19 \cdot 2) \\
10(6 \cdot 8) \\
56(38 \cdot 4) \\
14(9 \cdot 6) \\
38(26 \cdot 0) \\
3 \\
146\end{array}$ & $\begin{aligned} 7(9 \cdot 9) \\
8(11 \cdot 3) \\
23(32 \cdot 4) \\
9(12 \cdot 7) \\
24(33 \cdot 8) \\
4 \\
71\end{aligned}$ & $\begin{array}{r}98(23 \cdot 0) \\
49(11 \cdot 5) \\
142(33 \cdot 3) \\
31(7 \cdot 3) \\
106(24 \cdot 9) \\
14 \\
426\end{array}$ & $\begin{array}{l}x_{8}^{2}=28 \cdot 3 \\
p<0.001\end{array}$ \\
\hline $\begin{array}{l}\text { Type of vehicle driven: } \\
\text { Car }\end{array}$ & $166(77 \cdot 6)$ & $130(87 \cdot 2)$ & $69(92 \cdot 0)$ & $365(83 \cdot 3)$ & \\
\hline $\begin{array}{l}\text { Heavy goods or } \\
\text { commercial vehicle } \\
\text { Motorcycle } \\
\text { Other }\end{array}$ & $\begin{array}{r}20(9 \cdot 3) \\
28(13 \cdot 1) \\
2\end{array}$ & $\begin{array}{rr}14 & (9 \cdot 4) \\
5 & (3 \cdot 4) \\
0 & \\
149 & \end{array}$ & $\begin{array}{rr}5 & (6 \cdot 7) \\
1 & (1 \cdot 3) \\
0 & \\
75 & \end{array}$ & $\begin{array}{rr}39 & (8 \cdot 9) \\
34 & (7 \cdot 8) \\
& \\
438 & \end{array}$ & $\left\{\begin{array}{l}x_{4}^{2}=17 \cdot 4 \\
p<0 \cdot 01\end{array}\right.$ \\
\hline Total & 214 & 149 & 75 & 438 & \\
\hline $\begin{array}{l}\text { Driving licence required for } \\
\text { Yes } \\
\text { No }\end{array}$ & $\begin{array}{l}\text { ccupation: } \\
73(33 \cdot 8) \\
143(66 \cdot 2)\end{array}$ & $\begin{array}{l}80(53 \cdot 7) \\
69(46 \cdot 3)\end{array}$ & $\begin{array}{l}36(48 \cdot 0) \\
39(52 \cdot 0)\end{array}$ & $\begin{array}{l}189(43 \cdot 0) \\
251(57 \cdot 0)\end{array}$ & $\left\{\begin{array}{l}x_{2}^{2}=15.2 \\
p<0.001\end{array}\right.$ \\
\hline $\begin{array}{l}\text { Previous drinking/driving ce } \\
\text { Yes } \\
\text { No }\end{array}$ & $\begin{array}{l}\text { aviction: } \\
22(11 \cdot 2) \\
194(89 \cdot 8)\end{array}$ & $\begin{array}{r}32(21 \cdot 5) \\
117(78 \cdot 5)\end{array}$ & $\begin{array}{l}11(14 \cdot 7) \\
64(85 \cdot 3)\end{array}$ & $\begin{array}{r}65(14 \cdot 8) \\
375(85 \cdot 2)\end{array}$ & $\left\{\begin{array}{l}x_{2}^{2}=8.9 \\
p<0.05\end{array}\right.$ \\
\hline $\begin{array}{l}\text { Involved in accidents? } \\
\text { Yes } \\
\text { No }\end{array}$ & $\begin{array}{r}49(22 \cdot 7) \\
167(77 \cdot 3)\end{array}$ & $\begin{array}{r}42(28 \cdot 2) \\
107(71 \cdot 8)\end{array}$ & $\begin{array}{l}25(33 \cdot 3) \\
50(66 \cdot 7)\end{array}$ & $\begin{array}{l}116(26 \cdot 4) \\
324(73 \cdot 6)\end{array}$ & $\left\{\begin{array}{l}x_{2}^{2}=3 \cdot 6 \\
N S\end{array}\right.$ \\
\hline
\end{tabular}

Conversion: SI to traditional units-Alcohol: $1 \mathrm{mmol} / \approx \approx 4.6 \mathrm{mg} / 100 \mathrm{ml}$. *Significance of differences between and within age groups.

$\mathrm{n}=\uparrow 216 ; \ddagger 149 ; \$ 75$, unless otherwise stated.

TABLE II-Number (\%) of subjects with raised $\gamma$ glutamyltranspeptidase activity according to age group and police questionnaire variables. (Denominators shown in table I)

\begin{tabular}{|c|c|c|c|c|}
\hline & \multicolumn{3}{|c|}{ Subjects aged: } & \multirow{2}{*}{ Total } \\
\hline & $<30$ years & $30-44$ years & $\geqslant 45$ years & \\
\hline $\begin{array}{l}\text { Blood alcohol concentration: } \\
<33 \mathrm{mmol} / 1 \\
\geqslant 33 \mathrm{mmol} / 1 \\
\mathrm{p}^{\star}\end{array}$ & $\begin{array}{l}14(12 \cdot 7) \\
5(7 \cdot 2) \\
0 \cdot 32\end{array}$ & $\begin{array}{c}14(25 \cdot 9) \\
27(35 \cdot 5) \\
0.26\end{array}$ & $\begin{array}{r}7(25 \cdot 9) \\
14(34 \cdot 1) \\
0.59\end{array}$ & $\begin{array}{l}35(18 \cdot 3) \\
46(24 \cdot 7)\end{array}$ \\
\hline $\begin{array}{l}\text { Car owner: } \\
\text { Yes } \\
\text { No } \\
p^{\star}\end{array}$ & $\begin{array}{l}17(12 \cdot 6) \\
5(6 \cdot 2) \\
0 \cdot 17\end{array}$ & $\begin{array}{c}37(33 \cdot 9) \\
10(25 \cdot 0) \\
0.33\end{array}$ & $\begin{array}{l}17(28 \cdot 3) \\
5(33 \cdot 3) \\
0.76\end{array}$ & $\begin{array}{l}71(23 \cdot 4) \\
20(14 \cdot 7)\end{array}$ \\
\hline $\begin{array}{l}\text { Reason for arrest: } \\
\text { Moving traffic offence } \\
\text { Routine stop } \\
\text { Impaired driving } \\
\text { Information received } \\
\text { Accident } \\
\mathbf{p}^{\star}\end{array}$ & $\begin{array}{c}5(7 \cdot 9) \\
4(12 \cdot 9) \\
10(15 \cdot 9) \\
1(12 \cdot 5) \\
2(4 \cdot 5) \\
\text { NS } \\
\left(\mathrm{x}_{4}^{2}=4 \cdot 25\right)\end{array}$ & $\begin{array}{c}4(14 \cdot 3) \\
1(10 \cdot 0) \\
17(30 \cdot 4) \\
5(35 \cdot 7) \\
19(50 \cdot 0) \\
p<0 \cdot 05 \\
\left(x_{4}^{2}=12 \cdot 2\right)\end{array}$ & $\begin{array}{l}2(28 \cdot 6) \\
5(62 \cdot 5) \\
4(17 \cdot 4) \\
0 \\
10(41 \cdot 7) \\
\mathrm{p}<0 \cdot 05 \\
\left(\mathrm{x}_{4}^{2}=11 \cdot 3\right)\end{array}$ & $\begin{array}{r}11(11 \cdot 2) \\
10(20 \cdot 4) \\
31(21 \cdot 8) \\
6(19 \cdot 4) \\
31(29 \cdot 2)\end{array}$ \\
\hline $\begin{array}{l}\text { Type of vehicle driven: } \\
\text { Car } \\
\text { Heavy goods or commercial } \\
\text { vehicle } \\
\text { Motorcycle } \\
\mathbf{p}^{\star}\end{array}$ & $\begin{array}{l}14(8 \cdot 4) \\
5(25 \cdot 0) \\
3(10 \cdot 7) \\
0 \cdot 04\end{array}$ & $\begin{array}{l}44(33 \cdot 8) \\
3(21 \cdot 4) \\
0 \\
0.55\end{array}$ & $\begin{array}{l}19(27 \cdot 5) \\
3(60 \cdot 0) \\
0 \\
0 \cdot 15\end{array}$ & $\begin{array}{r}77(21 \cdot 1) \\
11(28 \cdot 2) \\
3(8 \cdot 8)\end{array}$ \\
\hline $\begin{array}{l}\text { Driving licence required for oce } \\
\text { Yes } \\
\text { No } \\
p^{\star}\end{array}$ & $\begin{array}{l}\text { on: } \\
9(12 \cdot 3) \\
13(9 \cdot 1) \\
0 \cdot 48\end{array}$ & $\begin{array}{c}32(40 \cdot 0) \\
15(21 \cdot 7) \\
0.02\end{array}$ & $\begin{array}{c}12(33.3) \\
10(25.6) \\
0.61\end{array}$ & $\begin{array}{l}53(28 \cdot 0) \\
38(15 \cdot 1)\end{array}$ \\
\hline $\begin{array}{l}\text { Previous drinking and driving } \mathrm{c} \\
\text { Yes } \\
\text { No } \\
\mathrm{p}^{\star}\end{array}$ & $\begin{array}{l}\text { tion: } \\
3(13 \cdot 6) \\
19(9 \cdot 8) \\
0 \cdot 48\end{array}$ & $\begin{array}{c}12(37 \cdot 5) \\
35(29 \cdot 9) \\
0.52\end{array}$ & $\begin{array}{l}2(18 \cdot 2) \\
20(31 \cdot 2) \\
0 \cdot 49\end{array}$ & $\begin{array}{l}17(26 \cdot 1) \\
74(19 \cdot 7)\end{array}$ \\
\hline $\begin{array}{l}\text { Involved in accidents? } \\
\text { Yes } \\
\text { No } \\
\mathrm{p}^{\star}\end{array}$ & $\begin{array}{c}2(4 \cdot 0) \\
20(12 \cdot 0) \\
0 \cdot 18\end{array}$ & $\begin{array}{c}21(50 \cdot 0) \\
26(24 \cdot 3) \\
0.003\end{array}$ & $\begin{array}{l}11(44 \cdot 0) \\
11(22 \cdot 0) \\
0.06\end{array}$ & $\begin{array}{l}34(29 \cdot 3) \\
57(17 \cdot 6)\end{array}$ \\
\hline
\end{tabular}

Conversion: SI to traditional units-Alcohol: $1 \mathrm{mmol} / \mathrm{l} \approx 4.6 \mathrm{mg} / 100 \mathrm{ml}$. * Significance of differences in prevalence within age groups; Fisher's exact test unless otherwise stated. 
TABLE III-Cross tabulations of blood alcohol concentrations, $\gamma$ glutamyltranspeptidase activities, accident involvement, and age

\begin{tabular}{|c|c|c|c|c|c|c|}
\hline & \multicolumn{3}{|c|}{ Accident involvement } & \multicolumn{3}{|c|}{ No accident involvement } \\
\hline & $\begin{array}{l}\text { Low } \\
\text { alcohol }\end{array}$ & $\begin{array}{l}\text { High } \\
\text { alcohol }\end{array}$ & No $(\%)$ & $\begin{array}{l}\text { Low } \\
\text { alcohol }\end{array}$ & $\begin{array}{l}\text { High } \\
\text { alcohol }\end{array}$ & No $(\%)$ \\
\hline \multicolumn{7}{|c|}{ Subjects aged $<30$ years } \\
\hline \multicolumn{7}{|c|}{$\gamma$ Glutamyltranspeptidase: } \\
\hline $\begin{array}{l}\text { Low } \\
\text { High }\end{array}$ & 17 & & $41(97 \cdot 6)$ & $\begin{array}{l}79 \\
13\end{array}$ & & $\begin{array}{l}119(86 \cdot 9) \\
18(13 \cdot 1)^{\star}\end{array}$ \\
\hline No $(\%)$ & $18(42 \cdot 8)$ & $24(57 \cdot 1)$ & & $92(67 \cdot 2)$ & $45(32 \cdot 8)$ & 137 \\
\hline \multirow{2}{*}{\multicolumn{7}{|c|}{ Subjects aged $\geqslant 30$ years }} \\
\hline & & & & & & \\
\hline High & 9 & & $\begin{array}{l}30(51 \cdot 7) \\
28(48 \cdot 3) \pm\end{array}$ & 45 & $\begin{array}{l}61 \\
22\end{array}$ & $\begin{array}{l}106(75 \cdot 7) \\
34(24 \cdot 3) \neq\end{array}$ \\
\hline No $(\%)$ & $24(41 \cdot 4)$ & $34(58.6) \subseteq$ & 58 & $57(40 \cdot 7)$ & $83(59 \cdot 3) \sqrt{6}$ & 140 \\
\hline
\end{tabular}

Significance of differences between subjects involved and not involved in accidents-Younger drivers: ${ }^{\star} p=0.005 ; t p=0.006$. Older drivers: $\neq p=0.001 ; \oint N S$.

Among those not involved in accidents the prevalence was $13 \cdot 1 \%(\mathrm{p}=0.05)$ The corresponding prevalences for raised blood alcohol concentration were $57 \cdot 1 \%$ and $32 \cdot 8 \%(\mathrm{p}=0 \cdot 006)$. A higher proportion of older drivers involved in accidents $(48.3 \%)$ had raised $\gamma$ glutamyltranspeptidase activities than older drivers not involved in accidents $(24 \cdot 3 \%)(\mathrm{p}=0.001)$, but the prevalences of high blood alcohol concentrations were similar $(58 \cdot 6 \%$ and $59 \cdot 3 \%$, respectively).

\section{Discussion}

As indicated in the introduction, studies of road traffic show an overall relation between accidents and alcohol concentrations. That mean alcohol concentrations rise with driver age is also well established..$^{7-9}$ Detailed relations are, however, more complicated, with accidents and accident severity most common in offenders under the age of $30 .{ }^{518} \mathrm{~A}$ reanalysis of the Grand Rapids Study noted that the relative accident rate rose faster as the alcohol concentration rose above $17 \mathrm{mmol} / \mathrm{l}(80 \mathrm{mg} / 100 \mathrm{ml})$ for drivers aged $25-34$ and 55-64 than for those aged 35-54. ${ }^{19}$ This paradoxical set of relations between alcohol consumption, age, and accidents is perhaps partly explained by the results of the present study.

A previous study showed a relation between $\gamma$ glutamyltranspeptidase activities and blood alcohol concentration among driving offenders. ${ }^{16}$ The present results, however, show no relation between blood alcohol concentration and accidents in older drivers. This is a more extreme result than that obtained in the Grand Rapids Study. ${ }^{2}$ There is, however, a strong association between raised $\gamma$ glutamyltranspeptidase activity and accidents in older offenders. Among young drivers the traditional, strong association between blood alcohol concentration and accidents is found. Focusing solely on measured blood alcohol concentration may therefore disguise a relation between chronic, rather than acute, alcohol abuse and accidents.

Young drivers are generally inexperienced with both alcohol and driving, and the acute effects of alcohol may make the dominant contribution to accident risk in this age group. Older drivers may be more experienced and relatively tolerant to these acute effects. Accidents in the older group could therefore be due to a combination of acute and chronic deterioration in driving skills, with chronic deterioration resulting from alcohol induced neuropsychological deficits. ${ }^{20-23} \gamma$ glutamyltranspeptidase activities and other indicators of chronic alcohol consumption may measure this factor more adequately than blood alcohol concentration.

The strong association between raised $\gamma$ glutamyltranspeptidase activities and accidents in drivers aged over 30 indicates that a large proportion of accidents may be accounted for by problem drinkers. A further indication that these drinkers may constitute a disproportionate degree of danger on the roads may be inferred from the relation between arrests for impaired driving and $\gamma$ glutamyltranspeptidase; drivers with a high $\gamma$ glutamyltranspeptidase activity but not involved in accidents were most commonly arrested for impaired driving.

The significantly high prevalence of raised enzyme activities in drivers aged over 30 who require a driving licence for their job is also disturbing. Particularly disturbing is the high prevalence among drivers of heavy goods and public service vehicles. At a time when the size of goods vehicles and the volume of traffic on the road system is increasing these results ought to be of widespread concern.

The Department of Transport's criterion for the high risk offender is two offences at $43 \mathrm{mmol} / \mathrm{l}(200 \mathrm{mg} / 100 \mathrm{ml})$ or two offences with refusals within 10 years. Despite the association with accidents most offenders with raised $\gamma$ glutamyltranspeptidase activities have alcohol concentrations below the high risk criterion of $43 \mathrm{mmol} / \mathrm{l}$, suggesting that alcohol concentration alone is a relatively poor indicator of problem drinking. ${ }^{16}$ In older offenders there is no significant association between blood alcohol concentration and accident involvement. Our results also indicate that there is unlikely to be a strong association between problem drinkers, as defined by raised $\gamma$ glutamyltranspeptidase activities, and previous convictions for drinking and driving. ${ }^{9}$ Difficulties in the identification of problem drinkers will be increased by low arrest rates and by the absence of calibration of electronic breath testing at two and a half times the legal concentration. ${ }^{24}$ This argues against basing the criteria for problem drinkers on two convictions or on alcohol concentration.

If the results of this study are confirmed the Department of Transport criteria must be missing a large proportion of drinking and driving offenders with alcohol problems and should be reviewed.

At present most problem drinkers among offending drivers are unknown to their general practitioners and therefore have not been offered help for their alcohol problems, which are sometimes exacerbated by loss of the driving licence. ${ }^{916}$ As a first step towards identification and treatment the Department of Transport should look at ways in which general practitioners can be informed when their patients have been convicted of drinking and driving. ${ }^{25}$ The Federal Republic of Germany and most states in the USA now have driver rehabilitation programmes. ${ }^{26} 27$ If our results in Tayside are representative there is a clear need for such programmes in the United Kingdom.

This study was funded by a grant from the Association of Police Surgeons of Great Britain. We thank Tayside's police and police surgeons for their support.

\section{References}

Departmental Committee, Department of the Environment. Drinking and driving. London: HMSO, 1976.

2 Borkenstein RF, Crowther RP, Shumate WB, Ziel WB, Zylman R. The role of the drinking driver in traffic accidents. Bloomington: Department of Police Administration, Indiana University, 1964.

3 Goehrs Y, Got J, L'Hoste L, Papoz L, Weill J. Alcohol and accidents. In: Proceedings of the ninth international conference on alcohol, drugs and traffic safety, 1983. (Available from $\mathrm{Dr} S \mathrm{Kaye}$, T-83 Secretariat, GPO Box 5067, Medical Sciences Campus, University of Puerto Rico, San Juan, Puerto Rico 00936.)

4 Goldberg L. Random tests in non-accident and accident involved drivers: epidemiological data, differential characteristics and the role of alcoholism. In: Proceedings of eighth international conference on alcohol, drugs and traffic safety. Stockholm: Almqvist and Wiksell, 1980.

5 Hendtlass J, Bock I, Ryan M. Differences between drivers injured and not injured in collisions in Victoria, Australia. In: Proceedings of eighth international conference on alcohol, drugs and traffic safery. Stockholm: Almqvist and Wiksell, 1980

6 Zylman R. Comparing collision drivers with the driving population at risk: a challenge for conventional methods. Behaviour Research In Highway Safety 1970;1:78-87.

7 Bonnichsen R, Solarz A. Alcohol and road traffic accidents with severe injury to the driver. In Proceedings of eighth international conference on alcohol, drugs and traffic safety. Stockholm Almqvist and Wiksell, 1980.

8 Storey VJ. Male and female drivers: differences observed in accidents. Crowthorne: Transport and Road Research Laboratory, 1977. (TRRL report No 761.)

9 Clayton AB, McCarthy PE, Breen JM. The male drinking driver: characteristics of the offender and his offence. Crowthorne: Transport and Road Research Laboratory, 1980. (TRRL supplementary report No 600.)

10 Whitehead TP, Clark CA, Whitfield AGW. Biochemical and haematological markers of alcohol intake. Lancet 1978;i:978-81.

11 Rosalki SP, Rau D. Serum gammaglutamyl transpeptidase activity in alcoholism. Clin Chim Acta 1972;39:41-7.

12 Petersson B, Trell E, Henningsen NC, Hood B. Risk factors for premature death in middle-aged men. BrMed $\mathcal{F} 1984 ; 288: 1264-8$.

13 Pikkarainen J, Pentilla A. Screening of arrested drunk drivers for alcoholism. In: Proceedings of eighth international conference on alcohol, drugs and traffic safery. Stockholm: Almqvist and Wiksell, 1980.

14 Geiselbrecht $W$, Kruger D, Finkel $M$. Use of gammaglutamyl transferrase in identifying motorists with alcohol problems in driver licensing tests. Blut Alkohol 1978;15:370-5.

15 Dunbar JA, Hagart J, Martin BT, Ogston SA, Devgun MS. Drivers, binge drinking, and gammaglutamyl transpeptidase. BrMed f 1982;285:103.

16 Dunbar JA, Martin BT, Devgun MS, Hagart J, Ogston SA. Problem drinking among drunk drivers. Br Med $\mathcal{J}$ 1983;286:1319-22.

17 Devgun MS, Dunbar JA, Hagart J, Ogston SA, Martin BT. Biochemical measurements and screening for alcohol abuse in drunk drivers. In: Proceedings of the ninth international conference on alcohol, drugs and traffic safety, 1983. (Available from Dr S Kaye, T-83 
Secretariat, GPO Box 5067, Medical Sciences Campus, University of Puerto Rico, San Juan, Puerto Rico 00936.

18 Mayhew DR. Alcohol, age and risk of accident involvement. In: Proceedings of ninth international conference on alcohol, drugs and traffic safety, 1983. (Available from Dr S Kaye, T-83 Secretariat, GPO Box 5067, Medical Sciences Campus, University of Puerto Rico, San Juan, Puerto Rico 00936.)

19 Allsop RE. Alcohol and road accidents: a discussion of The Grand Rapids Study. Crowthorne: Transport and Road Research Laboratory, 1966. (TRRL report No 6.)

20 Fine EW, Steer RA. Short-term spatial memory deficits in men arrested for driving while intoxicated. Am f Psychiatry 1979;136:594-7.

21 Tartar R. An analysis of cognitive deficits in chronic alcoholics. $f$ Nerv Ment Dis 1973;147:138-47. 22 Tartar R, Parsons O. Conceptual shifting in chronic alcoholics. 7 Abnorm Psychol 1971;77:71-5.

23 Robertson I. Does moderate drinking cause mental impairment [Editorial]? Br Med f 1984;289. 711-2.
24 Emerson VJ, Hollyhead R, Isaacs MD, Fuller NA, Hunt DJ. The measurement of breath alcohol f Forensic Sci Soc 1980;20:1.

25 Nightingale J. Problem drinking among drunk drivers. Br Med f 1983;286: 1648-9.

26 Spoerer E. Rehabilitation of drinking drivers in the Federal Republic of Germany. In: Proceedings of ninth international conference on alcohol, drugs and traffic safety, 1983. (Available from $\mathrm{Dr} S$ Kaye, T-83 Secretariat, GPO Box 5067, Medical Sciences Campus, University of Puerto Rico, San Juan, Puerto Rico 00936.)

27 Siegal HA. The intervention approach; drunk driver rehabilitation. In: Proceedings of ninth international conference on alcohol, drugs and traffic safety, 1983. (Available from Dr S Kaye, T-83 Secretariat, GPO Box 5067, Medical Scien 5067, Medical Sciences Campus, University of Puerto Rico, San Juan, Puerto Rico 00936.)

(Accepted 13 November 1984)

\title{
Paediatrics Among Ethnic Minorities
}

\section{Asian Families II: Conditions that may be found in the children}

\author{
JOHN BLACK
}

\section{Genetically determined conditions}

BLOOD DISEASES

$\beta$ thalassaemia is widely distributed throughout the Indian subcontinent, particularly in the north, though it is not nearly so common as in the Mediterranean area. More cases of homozygous $\beta$ thalassaemia (thalassaemia major) are now seen in Pakistani families in London than in Greek, Cypriot, and Italian communities (for further discussion on $\beta$ thalassaemia see article No 5: Families from the Mediterranean and Aegean regions). Moslem parents have more difficulty in accepting the ideas of genetic advice, antenatal testing, and termination of pregnancy than have parents from Mediterranean areas.

Haemoglobin $D$ disease may occur in combination with $\beta$ thalassaemia in children from northern India or Pakistan, and haemoglobin $\mathrm{E}$ thalassaemia occurs in Bengalis from Bangladesh. Both of these combined blood disorders result in chronic haemolytic anaemia with splenomegaly, requiring the same sort of treatment as homozygous $\beta$ thalassaemia.

Sickle cell disease is not common in those groups that have emigrated to Britain, though this possibility should be considered in families originating from the Nilgiri Hills in southern India. There are also small areas with a notable incidence of sickle cell trait in Maharashtra, Bihar, Uttar Pradesh and West Bengal ${ }^{1}$; (for further discussion on sickle cell disease see article 6: Afro-Caribbean (West Indian) and African families).

Glucose-6-phosphate dehydrogenase deficiency is fairly common throughout the northern part of the Indian subcontinent. The possibility of such a deficiency should always be considered in cases of neonatal jaundice when blood groups are compatible and in any cases of severe and sudden haemolytic anaemia that develop during an acute illness or as a result of taking certain drugs (for further discussion see later articles). When practicable G6PD deficiency should be excluded before giving primaquine for malaria.

Department of Child Health, King's College Hospital, London SE5 9RS JOHN BLACK, FRCP, honorary consultant paediatrician

\section{RECESSIVELY DETERMINED METABOLIC DISORDERS}

There is little doubt that the high incidence of recessively determined metabolic disorders and some of the more unusual malformations in Moslem families from Pakistan is due to the number of marriages among first and second cousins.

\section{Acquired diseases}

\section{IRON DEFICIENCY ANAEMIA}

Iron deficiency anaemia is the commonest form of anaemia in Asian children and is of dietary origin. Maternal iron deficiency in pregnancy and prematurity and low birth weight are both important factors, as is prolonged milk feeding and the late introduction of solids. Infants who are exclusively breast fed for a year or 18 months develop severe iron deficiency anaemia. The use of artificial milks, fortified with small amounts of iron, reduces the severity of the anaemia but does not necessarily prevent it.

A vegetarian diet in Britain, as eaten by strict Hindu families, results in iron deficiency, but many Hindu parents in Britain give their children meat and eggs. The peak incidence of iron deficiency is a: about 3 years, though for the reasons already discussed the condition may develop much earlier. On a vegetarian diet the best sources of iron are eggs (if these are part of the normal diet of the family), dried fruit, green vegetables, whole wheat chapatis, peas, beans, and other pulses (seeds of leguminous vegetables, which when split are known as "dahl"). If one member of a family is found to have iron deficiency anaemia the other members of the family should have haemoglobin concentrations measured and receive dietary advice from someone familiar with the diets of that particular community. Though not vegetarians, children from Bangladesh are also likely to have iron deficiency anaemia. ${ }^{2}$ Many Asian families have now adopted a partly European diet.

Poor economic circumstances in any group may result in a diet deficient in iron.

A child with iron deficiency anaemia who has been living in Asia from the age of 1 or who has become anaemic after a visit to the home country should be suspected of having hookworm disease, particularly if his or her response to treatment with iron is poor (for further discussion on hookworm disease see below). 